\title{
Prevalence of sleep-disordered breathing related to malocclusion in children
}

\author{
Prevalência de distúrbios respiratórios do sono relacionados a maloclusões em crianças \\ Prevalencia de trastornos del sueño respiratorio relacionados con maloclusiones en niños
}

Received: 11/27/2021 | Reviewed: 12/04/2021 | Accept: 12/11/2021| Published: 12/19/2021

Fanny Cavalcante Carrijo

ORCID: https://orcid.org/0000-0002-5135-0911

Faculdade Morgana Potrich, Brasil

E-mail: fannycavalcante1@gmail.com

Winicius Arildo Ferreira Araújo

ORCID: https://orcid.org/0000-0001-5529-7778

Universidade Estadual Paulista, Brasil

E-mail: Winiciusaraujo94@gmail.com

Iorrana Morais de Oliveira

ORCID: https://orcid.org/0000-0002-0341-727X

Universidade Federal de Jatai, Brasil

E-mail: iorranaoliveira@discente.ufj.edu.br

Crystina Alcântara Carvalho

ORCID: https://orcid.org/0000-0002-5427-3405

Faculdade Morgana Potrich, Brasil

E-mail: crystinacarvalho2018@gmail.com

Marcelo Costa Rodrigues

ORCID: https://orcid.org/0000.0002-6606-0538

Universidade Federal de Jatai, Brasil

E-mail: rodriguesmc17@gmail.com

Maria Tereza de Oliveira e Souza

ORCID: https://orcid.org/0000-0003-0292-7881 Faculdade Morgana Potrich, Brasil

E-mail: mariasouza@fampfaculdade.com.br

Glauco Issamu Miyahara

ORCID: https://orcid.org/0000-0002-5748-9412

Universidade Estadual Paulista, Brasil E-mail: glauco.miyahara@unesp.br

Grace Kelly Martins Carneiro

ORCID: https://orcid.org/0000-0001-6679-8930

Faculdade Morgana Potrich, Brasil

E-mail: carneirogkm.gc@gmail.com

\begin{abstract}
Sleep-disordered breathing is characterized by airway dysfunction that can occur in any age, but most prevalent in children, caused by the occurrence of respiratory effort, snoring or even by apnea during sleep. Therefore, the aim of this study was to survey the prevalence of sleep disorders associated with malocclusion in children aged 3 to 12 years in Mineiros, State of Goiás, Brazil. Material and Methods: this is a field research with a sample of 99 children affected by some type of sleep-disordered breathing and malocclusions. Data were collected through a questionnaire about sleep-disordered breathing and a clinical record carried out through intraoral clinical examination. Results: among the 24 children with SDB, 17 had SDB and Malocclusion, which is $70.8 \%$ of the children had SDB associated with malocclusion. Of the 75 children without SDB, 11 (14.7\%) had malocclusion. Conclusion: No significant differences were found between sleep-disordered breathing and sex-related malocclusions.
\end{abstract}

Keywords: Malocclusion; Orthodontics; Oral health; Bruxism; Apnea.

\section{Resumo}

Os distúrbios respiratórios do sono são caracterizados por disfunção das vias aéreas, que pode ocorrer em qualquer idade, mas mais prevalente em crianças, causada pela ocorrência de esforço respiratório, ronco ou mesmo por apneia durante o sono. Portanto, o objetivo deste estudo foi realizar o levantamento da prevalência dos Distúrbios Respiratórios do Sono (DRS) associados a maloclusão em crianças de 3 a 12 anos do município de Mineiros, Estado de Goiás, Brasil. Material e Métodos: trata-se de uma pesquisa de campo com uma amostra de 99 crianças acometidas por algum tipo de distúrbio respiratório do sono e maloclusões. Os dados foram coletados por meio da realização de um questionário sobre os distúrbios respiratórios do sono e de uma ficha clínica realizada por meio do exame clínico intrabucal. Resultados: dentre as 24 crianças com DRS, 17 apresentaram DRS e Maloclusão, ou seja 70,8\% das crianças que tinham DRS tinham má oclusão associada. Já as 75 crianças com ausência de DRS, 11 (14,7\%) 
apresentavam maloclusão. Conclusão: não foram encontradas diferenças significativas entre distúrbios respiratórios do sono e maloclusões relacionados ao sexo.

Palavras-chave: Má oclusão; Ortodontia; Saúde bucal; Bruxismo; Apnéia.

\section{Resumen}

Los trastornos respiratorios del sueño se caracterizan por una disfunción de las vías respiratorias, que puede ocurrir a cualquier edad, pero es más prevalente en los niños, causada por la aparición de esfuerzo respiratorio, ronquidos o incluso por apnea durante el sueño. Por lo tanto, el objetivo de este estudio fue sondear la prevalencia de trastornos del sueño asociados a maloclusión en niños de 3 a 12 años en Mineiros, Estado de Goiás, Brasil. Material y métodos: se trata de una investigación de campo con una muestra de 99 niños afectados por algún tipo de trastornos respiratorios del sueño y maloclusiones. Los datos se recogieron mediante un cuestionario sobre trastornos respiratorios del sueño y una historia clínica realizada mediante examen clínico intraoral. Resultados: de los 24 niños con TRS, 17 tenían TRS y Maloclusión, lo que representa un 70,8\% de los niños con TRS asociado a maloclusión. De los 75 niños sin TRS, 11 (14,7\%) tenían maloclusión. Conclusión: No se encontraron diferencias significativas entre los trastornos respiratorios del sueño y las maloclusiones relacionadas con el sexo.

Palabras clave: Maloclusión; Ortodoncia; Salud bucal; Bruxismo; Apnea.

\section{Introduction}

Sleep-disordered breathing (SDB) is common in children, with a higher incidence in preschool children, with no gender predominance. It is a syndrome characterized by airway dysfunction, caused by the occurrence of respiratory effort during sleep, followed by primary snoring or even by obstructive sleep apnea. Malocclusions, on the other hand, are deviations from normality that affect the dental arch, facial bones or both and result in aesthetic, dental and functional problems (Andrade et al., 2020 e Carvalho et al., 2014).

SDB has a multifactorial etiology; however, the main risk factors for the occurrence of SDB include tonsillar hypertrophy, dentofacial anomalies and malocclusions, which can trigger mouth breathing. Persistent mouth breathing affects the functioning of the stomatognathic system. (Rodrigues et al., 2020) Which can cause vertical facial enlargement, facial asymmetry, muscle hypotonia, altered resting posture of the lips and tongue, atypical swallowing, retrognathism, maxillary atresia and dental malocclusions. (Motonaga et al., 2000; Motta et al., 2009) That is the importance of being aware of SDB and malocclusions, in which the child has developed. Thus, the most viable and indicated is to undergo treatment during mixed dentition.

The prevalence of malocclusions varie, ranging from $12 \%$ to $97.7 \%$. This variation is due to numerous factors, from socioeconomic conditions to environmental factors. (Lopes et al., 2019; Carneiro et al., 2021; Pereira et al., 2017) Among the SDBs, the prevalence of apnea in children varies from $0.7 \%$ to $3 \%$ between 2 and 6 years of age and primary snoring with a prevalence between 7\% and 9\% of children aged 1 to 10 years. (Silva et al., 2021; de Machado Gomes et al., 2012)

For accurate diagnosis, one of the complementary exams is polysomnography, monitoring physiological variables during sleep with audio and video recording. Some of these factors will be checked, for example: brain and muscle electrical activity, eye movement, airflow in breathing, respiratory effort and blood oxygen levels. (Barbosa et al., 2021; da Silva Rochaet al., 2020).

The treatment is carried out by a multidisciplinary intervention. Relating to Dentistry, the treatment for SDB is performed using intraoral appliances, namely: tongue retainers, soft palate elevators and jaw re-positioners and, for the treatment of malocclusions, it is necessary to analyze the type of alteration present in the child for that a more adequate treatment plan can be drawn up. (Thomé et al., 2020; Aroucha Lyra et al., 2020; Vazquez et al., 2020) Therefore, treatment carried out during childhood by a multidisciplinary team has satisfactory results and a better prognosis than when performed in adulthood. (Carvalho et al., 2014).

It is very important that the dental surgeon be aware of these disorders, identifying the types of malocclusions that 
may be related. However, despite the clinical routine, the diagnosis remains a challenge. Therefore, this study aimed to verify the prevalence of SDB and malocclusion in children aged 3 to 12 years, as well as advise if necessary, the most appropriate treatment for each case.

\section{Methodology}

This is a cross-sectional research, with a descriptive and quantitative approach (Rebouças et al., 2017; Viana et al. 2015). Data was collected, through a questionnaire about sleep-disordered breathing, and the analysis of clinical record data collected after an intraoral and extra oral examination from January to July of 2021, carried out at Faculty FAMP, Mineiros Goiás, Brazil, toda metodologia foi utilizada apartir de estudos com escopo semelhantes (Carneiro et al., 2021; Barbosa et al., 2021; Saretto et al., 2019; Monarca et al., 2018).

Ninety-nine children aged from 3 to 12 years were evaluated, analyzing the presence of any type of SDB and malocclusion. Parents/guardians answered the questionnaire where the SDB was identified through snoring, breathing effort, apnea, bruxism, among other related problems. Soon after, the children underwent an intraoral clinical examination in which the examiners filled out the form about the types of malocclusions present, such as open-bite, deep-bite, crossbite, and crowding. Arches and Angle classes were also evaluated. Thereafter, all participants received verbal and printed instructions. Two trained examiners, using the dental chair, under artificial lighting, performed clinical examinations.

The research consisted of a non-probabilistic sample with parents/guardians of all selected children. The questionnaire was applied in an interview format to everyone who agreed to participate, signing the Informed Consent Form. The questionnaire was applied according to Alencar et al. (2020), who reported in their review, that most authors use questionnaires for the diagnosis of bruxism, due to its consolidated and applied form for diagnosis, it is also easy to handle and access to data, but additional to this was performed clinical examinations on patients in this study.

The results were stored and tabulated in Microsoft Excel @ 2016 program. The data was analyzed by checking the frequencies and percentages. The chi-square test was performed. The results were expressed in the form of tables. P-value < 0.05 was considered statistically significant.

\subsection{Ethics approval}

The study was approved by the Ethics and Research Committee on Human Beings of the University Center of Santa Fé do Sul - UNIFUNEC (CAAE: 31584020.9.0000.5428).

\section{Results}

Descriptive statistical analysis of data from 99 children analyzed was performed, shown in Table 1, in absolute data, mean, standard deviation for quantitative variables. Significant variables at $95 \%$ were analyzed to verify whether there was a difference in the presentation of disorders between the sexes and/or association of SDB and malocclusion, a Chi-square or Fisher's exact test was performed, when necessary. For age, a Data Normality Test was performed. The program used to perform the analyzes was an Excel spreadsheet, version 2016. 
Table 1 - population distribution according to age (years) and sex.

\begin{tabular}{cccc}
\hline & Age $($ mean \pm SD) & Sex & Frequency (\%) \\
\hline Female & $8,50 \pm 2,3$ & 52 & 53 \\
Male & $9,10 \pm 2,5$ & 47 & 48 \\
\hline
\end{tabular}

Source: Authors.

Table 1 shows the results of the age distribution of the population studied. $53 \%$ were female with a mean age of 8.5 years, and $48 \%$ male with a mean age of 9.1 years.

Regarding Table 2, the results of the population distribution regarding the presence or absence of SDB are displayed. Among the 99 children analyzed, 24 had SDB (prevalence of 24\%). SDB was more frequent in female children 27\% ( $\mathrm{n}=14$ ) and among male children it was $21 \%(n=10)$. Although the prevalence in this population was high $(24 \%)$, no statistically significant difference was found in the results between genders and DRS ( $\mathrm{p}=0.62)$.

Table 2. Distribution of children studied according to the presence or absence of sleep-related disorders (SDB) and prevalence of SDB in relation to gender

\begin{tabular}{cccccc}
\hline \multicolumn{5}{c}{ Sleep-disordered breathing } & \\
\hline Sex & \multicolumn{2}{c}{ Presence } & Absence & SDB according to sex & P \\
\hline Female & 52 & 14 & 38 & $27 \%$ & 0,62 \\
Male & 47 & 10 & 37 & $21 \%$ & \\
\hline Total $(\%)$ & 99 & $24(24 \%)$ & $75(76 \%)$ & & \\
\hline
\end{tabular}

SDB, Sleep-disordered breathing. Source: Authors.

Table 3 presents the results of presence or absence of malocclusions in the studied population. Among the 99 children analyzed, 28 had malocclusions, and there was no statistically significant difference in the results between genders and malocclusion $(\mathrm{p}=0.67)$. Malocclusion was more frequent among female children, 31\% ( $\mathrm{n}=16)$, and 26\% ( $\mathrm{n}=12)$ of male children had some type of malocclusion.

Table 3. Distribution of children studied according to the presence or absence of malocclusion and prevalence of malocclusion in relation to gender.

\begin{tabular}{cccccc}
\hline \multicolumn{7}{c}{ Sex } & & Presence & Absence & Malocclusion according to sex & P \\
\hline Female & 52 & 16 & 36 & $31 \%$ & 0,67 \\
Male & 47 & 12 & 35 & $26 \%$ & \\
\hline Total & 99 & $28(28 \%)$ & $71(72 \%)$ & & \\
\hline
\end{tabular}

Source: Authors.

According to the data obtained in Table 4, of the 24 children with SDB and, correlating with the presence of malocclusion between the sexes, it was found that $70.8 \%(\mathrm{n}=17$ children) who had SDB also presented malocclusion. $92.9 \%$ of the children were female and $40 \%$ male. 
Analyzing Table 5, of the 75 children without SDB and verifying the presence of malocclusion between the sexes, it was found that $14.7 \%(\mathrm{n}=11)$ of the children did not have SDB but presented malocclusion, with $18.4 \%$ of children were female and $10.8 \%$ male, with no statistical difference between the absence of SDB and malocclusion according to gender.

Table 4. Distribution of studied children with SDB and malocclusion.

\begin{tabular}{ccccc}
\hline \multicolumn{5}{c}{ Relation of the presence of SDB and malocclusion } \\
\hline Sex & Total with SDB & malocclusion presence & Absence of malocclusion & P \\
\hline Female & 14 & $13(92,9 \%)$ & 1 & 0,27 \\
Male & 10 & $4(40,0 \%)$ & 6 & \\
\hline Total & 24 & $17(70,8 \%)$ & 7 \\
\hline
\end{tabular}

SDB, Sleep-disordered breathing. Source: Authors.

Table 5. Distribution of children studied without the presence of SDB and malocclusion.

\begin{tabular}{ccccc}
\hline \multicolumn{5}{c}{ Relation of SDB absence and malocclusion } \\
\hline Sex & Total without SDB & malocclusion presence & Absence of malocclusion & P \\
\hline Female & 38 & $7(18,4 \%)$ & 31 & 0,64 \\
Male & 37 & $4(10,8 \%)$ & 33 & \\
\hline Total & 75 & $11(14,7 \%)$ & 64 \\
\hline
\end{tabular}

SDB, Sleep-disordered breathing. Source: Authors.

Assessing the correlation between the presence of SDB and malocclusion, it was evidenced that there is a correlation between the presence of SDB and the presence of malocclusion, and it is important to note that $70.8 \%$ of children with SDB also had malocclusion (Table 4) and that $14.7 \%$ of children who did not have SDB had malocclusion.

\section{Discussion}

Of the 99 children analyzed in this study, 24 (24\%) had SDB (Table 2) and 28 (28\%) had malocclusion (Table 3), which are high prevalence for a population. Of these, 24 children with SDB (Table 4), 17 children had SDB and malocclusion, that is, $70.8 \%$ of the children who had SDB had associated malocclusion. Of the 75 children without SDB (Table 5), 11 $(14.7 \%)$ had malocclusion. The results demonstrate the great importance of knowing and diagnosing SDB due to its high prevalence.

The children participating in this study were aged between 03 and 12 years, there was a predominance of females $53 \%$ $(n=52)$ compared to males with $47 \%(n=47)$. Although in the present study, the population of female children had a higher prevalence of SDB and malocclusion, there was no statistically significant difference between genders.

In the evaluation of SDB, among the 99 children, 24 (24\%) of them had a sleep disorder, identified through questionnaires. As well as Vázquez-Casas et al. (2020), in their study, they pointed out a prevalence of $22.8 \%$ of the sample had SDB. Rodrigues et al. (2020) reported a prevalence of $22.0 \%$. The prevalence was similar to the investigation carried out in Gomes, et al. (2012) indicated a prevalence of $12 \%$ in the population of children aged 1 to 10 years. Di Carlo et al. (2020) reported a prevalence of $9.7 \%$. 
However, Saretto et al. (2019) pointed out in their study that SDB was manifested in $41.5 \%$ of the evaluated population. Silva et al. (2017) evaluated 64 patients and 61\% had disorders. Motta et al. (2014) presented the index of $62.5 \%$ of the population. Barbosa et al. (2021) indicated in their work a prevalence of $83 \%$ of the patients in the studied group. Fernandes et al. (2020), in their studies carried out in Pará, found a prevalence of $26.2 \%$ of SDB.

Among the 99 children evaluated in this study, aged between 03 and 12 years, 28 (28\%) of them had malocclusion identified through clinical examination performed in each patient. The prevalence was similar to the investigation carried out by Pereira et al. (2017) showed a prevalence of 33.3\% of children had malocclusions. Martins et al. (2019) found 31.3\% of malocclusion. Leôncio et al. (2015) showed a prevalence of $38.2 \%$ of malocclusion in the evaluated children. Alves et al. (2020) found a prevalence of $42,5 \%$ of malocclusions. Carneiro et al. (2021) reported a prevalence of $73 \%$ of malocclusion in the studied population. Rodrigues et al. (2020) reported a prevalence of $84.8 \%$ of malocclusion. Bittencourt and Machado (2010) found a prevalence of malocclusion of $85.7 \%$ of children. For both Pimenta et al. (2018) and Vázquez-Casas (2020) the prevalence of malocclusion was $83.9 \%$. Werneck et al. (2011) showed a prevalence higher than $90 \%$ of the studied population. Fernandes et al. (2020) reported $100 \%$ prevalence of malocclusion.

As in our study, other authors also corroborate the correlation between SDB and Malocclusion. Di Carlo et al. (2020), Rodrigues et al. (2020), and Ghafournia et al. (2012) showed a correlation between SDB and malocclusion. Saretto et al. (2019) and Motta et al. (2014) pointed out in their study that SDB was statistically associated with the presence of morphological and functional changes in the face. Carneiro et al. (2021) showed that there is an association between sleepdisordered breathing and malocclusions. However, Rodrigues et al. (2020) did not show a statistically significant correlation between SDB and malocclusion, diverging from what was observed in the present study. Barbosa et al. (2021) reported a low relationship between patients with sleep disorders and bruxism, in a polysomnographic study with 101 adult patients.

Rodrigues et al. (2020) observed a higher prevalence of SDB in children with malocclusion. Gomes et al. (2012) warned that SDB can influence the growth and development of craniofacial structures and, therefore, dental occlusion and in their study they indicated that the most prevalent age was 9 to 11 years old. However, the proportion that caused more seriousness was in children in early childhood, who are at the beginning of their school phase and who are not accustomed to their new routine, since respiratory disorders are pathological conditions that affect the respiratory system and its correct functioning.

\section{Conclusion}

Based on the methods of this study, it is concluded that no significant differences were found between sleepdisordered breathing and sex-related malocclusions, and that there was a strong and positive correlation between SDB and malocclusion. Children with SDB and malocclusions present in this study were referred for multidisciplinary treatment offered at the institution. However, more research related to the topic is needed to identify the prevalence of malocclusion and SDB in other populations, then verifying whether there is relation to the environment, age, population phenotype or socioeconomic conditions. As well as, etiologic predictors of malocclusions and SDB, and their prevalence. This study contributes to scientific knowledgement, highlighting the importance of early diagnosis and treatment for all patients.

\section{References}

Alencar, L. B. B., Silva, I. L., de Sousa, S. C. A., de Araújo, V. F., \& Moura, C. (2020). Fatores associados ao bruxismo em estudantes universitários: uma revisão integrativa. Research, Society and Development, 9(7), e29973728-e29973728

Alves, D. O., Barbosa, F. R., Colares, V., Santos, C. D. F. B. F., de Menezes, V. A., \& Godoy, F. (2020). Maloclusão e bullying em adolescentes escolares. Research, Society and Development, 9(10), e699108403-e699108403. 
Andrade, M. A., Moura, A. B. R., Medeiros, F. L. S., Matos, N. O., Goes, V. N., Gomes, L. L., Lima, F. O., Cavalcanti, RBMS, Araújo Neto, APP, Alves, MRF, Alves, MASG, Penha, ES, Guênes, GMT \& Oliveira Filho, AA. (2020). Relationship between oclusions and parafunctional habits in early childhood. Research, Society and Development, 9(7):1-12. e484974260.

Aroucha Lyra, M. C., Aguiar, D., Paiva, M., Arnaud, M., Filho, A. A., Rosenblatt, A., Thérèse Innes, N. P., \& Heimer, M. V. (2020). Prevalence of sleepdisordered breathing and associations with malocclusion in children. Journal of Clinical Sleep Medicine, 16(7), 1007-1012. https://doi.org/10.5664/jcsm.8370

Barbosa, I. dos S., Souza, J. C., Muller, P. de T. G., Brito, P. O. C., Augusto, C. T., \& Cantarelli, I. de A. C. (2021). Avaliação dos Distúrbios do Sono de pacientes submetidos à Polissonografia. Research, Society and Development, 10(1), e40110111738. https://doi.org/10.33448/rsd-v10i1.11738

Bittencourt, M. A. V., \& Machado, A. W. (2010). Prevalência de má oclusão em crianças entre 6 e 10 anos: um panorama brasileiro. Dental Press Journal of Orthodontics, 15(6), 113-122. https://doi.org/10.1590/S2176-94512010000600015

Carneiro, G. K. M., Rodrigues, M. C., Araújo, W. A. F., \& De Almeida Jardim, G. (2021). Prevalência De Maloclusões Em Crianças de 3 a 12 anos de idade no município de Mineiros-Goiás. Facit Business and Technology Journal, 1(29).

Carneiro, G. K. M., Rodrigues, M. C., Araujo, W. A. F., Neves, A. C. D., \& Ferreira, L. P. A. (2021). Relação dos distúrbios respiratórios do sono associado ao desenvolvimento das maloclusões: Revisão De Literatura. Revista Saúde Multidisciplinar, 9(1).

Carvalho, F. R., Lentini-Oliveira, D. A., Carvalho, G. M. M., Singer, J. M., Prado, L. B. F., Prado, G. F., \& Carvalho, L. B. C. (2014). Intra- and interobserver agreement in the diagnosis of malocclusion in sleep-disordered breathing. Arquivos de Neuro-Psiquiatria, 72(2), 114-118. https://doi.org/10.1590/0004282X20130214

da Silva Rocha, O. K. M., da Silva Barros, C. C., da Silva, L. A. B., Souza Júnior, E. F., Morais, H. H. A., \& da Costa Migue1, M. C. (2020). Peripheral compound odontoma: A rare case report and literature review. Journal of Cutaneous Pathology, 47(8), 720-724. https://doi.org/10.1111/cup.13676

de Machado Gomes, A., dos Santos, O. M., Pimentel, K., Marambaia, P. P., Gomes, L. M., Pradella-Hallinan, M., \& Lima, M. G. (2012). Quality of life in children with sleep-disordered breathing. Brazilian Journal of Otorhinolaryngology, 78(5), 12-21. https://doi.org/10.5935/1808-8694.20120003

Di Carlo, G., Zara, F., Rocchetti, M., Venturini, A., Ortiz-Ruiz, A. J., Luzzi, V., Cattaneo, P. M., et al. (2020). Prevalence of Sleep-Disordered

Breathing in Children Referring for First Dental Examination. A Multicenter Cross-Sectional Study Using Pediatric Sleep Questionnaire. International Journal of Environmental Research and Public Health, 17(22), 8460. MDPI AG. Retrieved from http://dx.doi.org/10.3390/ijerph17228460

Fernandes, F. A. A., Tiago, C. M., Fernandes, L. A. A., Quaresma, J. N., \& NOUER, P. R. A. (2020). Prevalência Das Maloclusões Em Estudantes Das Redes Municipal E Estadual Do Município De Augusto Corrêa, Pará. Facit Business and Technology Journal, 1(13).

Ghafournia, M., \& Hajenourozali Tehrani, M. (2012). Relationship between Bruxism and Malocclusion among Preschool Children in Isfahan. Journal of Dental Research, Dental Clinics, Dental Prospects, 6(4), 138-142. https://doi.org/10.5681/joddd.2012.028

Martins, L. P., Bittencourt, J. M., Bendo, C. B., Vale, M. P., \& Paiva, S. M. (2019). Má oclusão e vulnerabilidade social: estudo representativo de adolescentes de Belo Horizonte, Brasil. Ciência \& Saúde Coletiva, 24(2), 393-400. https://doi.org/10.1590/1413-81232018242.33082016

Motonaga, S. M., Berte, L. C., \& Anselmo-Lima, W. T. (2000). Respiração bucal: causas e alterações no sistema estomatognático. Rev. bras. otorrinolaringol, 373-379.

Motta, L. J., Martins, M. D., Fernandes, K. P. S., Mesquita-Ferrari, R. A., Biasotto-Gonzalez, D. A., \& Bussadori, S. K. (2009). Relação da postura cervical e oclusão dentária em crianças respiradoras orais. Revista CEFAC, 11(suppl 3), 298-304. https://doi.org/10.1590/S1516-18462009000700004

Pereira, M. R., Jardim, L. E., Figueiredo, M. C., \& Faustino-Silva, D. D. (2017). Prevalência de má oclusão em crianças de quatro anos de idade e fatores associados na Atenção Primária à Saúde. Stomatos, 23(45), 49-58.

Pimenta, A. C. M. (2018).Prevalência de má-oclusão e fatores associados numa população pré-escolar do concelho de Lisboa (Doctoral dissertation).

Poluha, R. L., Stefaneli, E. Á. B., \& Terada, H. H. (2016). A Odontologia na sindrome da apneia obstrutiva do sono: diagnóstico e tratamento. Revista Brasileira de Odontologia, 72(1/2), 87. https://doi.org/10.18363/rbo.v72i1/2.588

Rebouças, A. G., Zanin, L., Ambrosano, G. M, \& Flório, F. M. (2017). Fatores individuais associados à má oclusão em adolescentes. Ciênc. Saúde coletiva. 22(11). 3723-3732. https://doi.org/10.1590/1413-812320172211.04972016

Rodrigues, J. A., Azevedo, C. B., Chami, V. O., Solano, M. P., \& Lenzi, T. L. (2020). Sleep bruxism and oral health-related quality of life in children: A systematic review. International Journal of Paediatric Dentistry, 30(2), 136-143. https://doi.org/10.1111/ipd.12586

Saretto, C. B., Godoi, B., Schmitz, D., \& Pedro, V. T. (2019). Prevalência de distúrbios do sono, alterações de alinhamentos posturais e morfológicos faciais de acordo com o padrão respiratório de crianças do ensino fundamental. Seminário de Iniciação Científica e Seminário Integrado de Ensino, Pesquisa e Extensão, e22313-e22313.

Silva Júnior, J. L. R., Conde, M. B., Corrêa, K. de S., Rabahi, H., Rocha, A. A., \& Rabahi, M. F. (2017). Sleep-disordered breathing in patients with COPD and mild hypoxemia: prevalence and predictive variables. Jornal Brasileiro de Pneumologia, 43(3), 176-182. https://doi.org/10.1590/s180637562016000000051

Silva, P. M. J., Feitoza, C. C., Franco-Micheloni, A. L., \& Pizzol, K. D. C. (2021). Síndrome da apneia e hipopneia obstrutiva do sono na infância: aspectos odontológicos. Revista Brasileira Multidisciplinar, 24(1). https://doi.org/10.25061/2527-2675/ReBraM/2021.v24i1.723 
Research, Society and Development, v. 10, n. 16, e598101623984, 2021

(CC BY 4.0) | ISSN 2525-3409 | DOI: http://dx.doi.org/10.33448/rsd-v10i16.23984

Thomé, G., Bernardes, S. R., Guandalini, S., \& Guimarães, M. C. V. (2020). Manual de boas práticas em biossegurança para ambientes odontológicos. Conselho federal de odontologia.

Vázquez-Casas, I., Sans-Capdevila, O., Moncunill-Mira, J., \& Rivera-Baró, A. (2020). Prevalence of sleep-related breathing disorders in children with malocclusion. Journal of clinical and experimental dentistry, 12(6), e555-e560. https://doi.org/10.4317/jced.56855

Viana, M. O., Lima, E. I., Menezes, J. N. R. \& Olegario, N. B. C. (2015). Avaliação de sinais e sintomas da disfunção temporomandibular e sua relação com a postura cervical. Rev. odontol. UNESP. 44(3). 125-130. https://doi.org/10.1590/1807-2577.1071

Werneck, E. C., Mattos, F. S., Silva, M. G. da, Prado, R. F. do, Carvalho, G. L., \& Araujo, A. M. (2011). Prevalência das maloclusões em crianças préescolares no município de lavrinhas, SP. Colloquium Vittae, 03(2), 27-33. https://doi.org/10.5747/cv.2011.v03.n2.v050 